\title{
Efficiency of three buffers for extracting $\beta$-glucosidase enzyme in different soil orders: Evaluating the role of soil organic matter
}

\author{
Viviana Gutiérrez ${ }^{1, *}$; Rodrigo Ortega-Blu²; Mauricio Molina-Roco'; María \\ M. Martínez ${ }^{2,3}$
}

${ }^{1}$ Agriservice Research Laboratory, Rinconada \#9139, Santiago 7650208, Chile.

2 Grupo de Investigación en Suelo, Planta, Agua y Ambiente (GISPA), Universidad Técnica Federico Santa María, Santiago 7660251, Chile.

3 TROPEN-Tropical Crops, Institute of Crop Science and Resources Conservation INRES Bonn Universität, Auf dem Hugel 6, 53121, Bonn, PC, 531113, Germany.

Received September 14, 2017. Accepted December 1, 2017.

\begin{abstract}
The objective of this research was to evaluate extraction methods for $\beta$-glucosidases comparing three buffer solutions (MUB, acetate, and maleate) at different incubation times $(0.5 \mathrm{~h}$ to $10 \mathrm{~h})$ and in three different soil orders (Mollisols, Andisols and Ultisols). Seven acidic soils were evaluated, showing differences in $\mathrm{pH}, \mathrm{OM}$, and clay contents. To evaluate the effect of OM as enzymes source, one soil of each order was treated to partially remove its OM and then the enzyme assay was performed. When using MUB and maleate buffers the highest (32 and $31 \mu \mathrm{g}-p \mathrm{NP}$ g-soil ${ }^{-1} \mathrm{~h}^{-1}$ in average, respectively) were found, and the latter was significantly ( $\mathrm{p}$ $<0.050)$ correlated with the soil clay content. The activity obtained with acetate buffer was much lower $(38.2$ $\mu \mathrm{g}-p \mathrm{NP}$ g-soil ${ }^{-1} \mathrm{~h}^{-1}$ in average). The use of MUB buffer with $1 \mathrm{~h}$ of incubation is suggested as extraction method, showing good reproducibility and allowing to express higher enzyme potential for soil comparisons. For the Andisol and Ultisol, the enzyme activity significantly decreased with the OM removal (\%) indicating that $\mathrm{OM}$ is the major source of the measured $\beta$-glucosidase activity, while a different trend was observed for the Mollisol, in which the mineral fraction (mainly 2:1 type clay) appears to be involved in the increased enzyme activity displayed after the initial OM removal.
\end{abstract}

Keywords: soil hydrolases; buffer solutions; soil organic matter; soil quality; volcanic soils.

\section{Introduction}

Soil enzymes play biochemical functions in the overall process of organic matter (OM) turnover in agricultural systems. They are important in catalyzing several reactions needed for different processes of microorganisms in soils, the stabilization of soil structure, the decomposition of organic wastes, OM formation, and nutrient cycling, thus providing an early indication of the trajectory of a soil subjected to changes in agricultural management. Extracellular enzymes produced by microorganisms have a strong influence on the decomposition of soil OM and the continuous flux of different elements in the soil (Kieloaho et al., 2016). Most authors consider enzyme activity as an early and sensitive soil indicator to evaluate the degree of degradation, the impact of pollution, the effect of crop growth and agronomic practices, the effect of organic materials, and changes of environmental conditions on microbial activity (Alvear et al., 2005; Fincheira-Robles et al., 2016; Gianfreda et al., 2005; Kabiri et al., 2016; Li et al., 2017).

Cellulose in soils is derived mainly from

* Corresponding author

E-mail: viguti86@gmail.com (V. Gutiérrez). 
plant residues, with a small amount derived from fungal or bacterial biomass (Deng and Tabatabai, 1994). The degradation of this polymer represents rapidly assimilated carbon (C) for microbial growth, and the enzymes involved, such as $\beta$-glucosidases, can be used as indicators of soil quality, due to their central role in the cycling of organic material (Adetunji et $a l .$, 2017). These enzymes are the most abundant and easily detected of the three groups of enzymes participating in the degradation of cellulose in the soil and are rarely limited by substrate (Knight and Dick, 2004; Baldrian et al., 2013).

$\beta$-Glucosidases, as free enzymes in the soil solution, normally have a short-lived activity, because they can be rapidly degraded, denatured or irreversible inhibited. However, a certain proportion of these free enzymes can be adsorbed on soil minerals or through incorporation into humic material, affecting their catalytic potential but enabling enzyme activity to persist (Burns et al., 2013). According to this, enzyme extraction is a widespread tool to determine enzymatic activity in soils. This procedure is easy to implement, although it should be adapted to the particular conditions of the soils under study. The process should be evaluated and optimized according to the chemical composition and concentration of extraction buffer (Blankinship et al., 2014), $\mathrm{pH}$, temperature, reaction time, and substrate concentration, because of extracellular enzymes are found free in the aqueous phase of soil, but are rapidly inactivated by degradation, denaturalization or absorption by soil clays (Knight and Dick, 2004; Nannipieri et al., 2002). Due to enzyme origin (from bacteria, fungi, plants, and a range of macroinvertebrates), different enzyme location (intra or extracellular), matrix associations (alive or dead cells, clays or / and humic molecules) and assay laboratory conditions, it has been demonstrated that it is of a great importance to optimize the procedures to obtain the best values according to intrinsic soil properties
(Bowles et al., 2014; Dick et al., 1996; Gianfreda and Ruggiero, 2006; Schimel et al., 2017). For these reasons, optimizing the methods is an everlasting need before using biochemical parameters as soil quality indicators.

At a very simple level, an enzyme assay consists of adding a known amount of soil to a solution containing a standard substrate at a certain concentration and measuring the rate at which the substrate is converted into a product (Verchot and Borelli, 2005). The procedure uses a substrate of low viscosity like carboxymethylcellulose to quantify glucose as end reaction product (Deng and Tabatabai, 1994), or highly sensitive techniques linked to substrate analogs as p-nitrophenol, 4-methylumbelliferone (MUF), 7-amino4-methylcoumarin, acridine orange, among others. This technique, compared with traditional colorimetric techniques, permit a higher sensitivity and precision, the interpretation of the results is simple, provide an opportunity to detect enzymes activities in small samples and/or in those with low activity, and are time-efficient (Dick et al., 1996; Gianfreda and Ruggiero, 2006).

Until 1970, buffer saline solutions were used to extract soil enzymes, and then phosphate, citrate or pyrophosphate buffers and organic acids like ethylenediaminetetraacetic acid (EDTA) started to be evaluated. The main problem was that brown compounds were obtained, suggesting that enzymes were bound to $\mathrm{OM}$ surface. Later on, Batistic et al. (1980) demonstrated that a mixture of $0.2 \mathrm{M}$ phosphate with $0.2 \mathrm{M}$ EDTA $(\mathrm{pH}=8)$ was effective for the extraction of hydrolases removing organo-mineral complexes and obtaining free enzymes associated with soil colloids. Kanerva et al. (2013) obtained pure extracts using phosphate buffer at $\mathrm{pH}=6$, while a higher $\mathrm{pH}$ (7.7) co-extracted OM. Thus, $\mathrm{pH}$ values in the range from 6 to 7 are preferred as the adequate range for extraction, since enzyme activity is preserved, and the extraction of large amounts of $\mathrm{OM}$ is 
minimized (Masciandaro et al., 2008). Buffer solutions are also preferred for comparisons of enzymatic potential when considering different soils types (Tabatabai and Dick, 2002). The objectives of this research were to evaluate and compare extraction methods for $\beta$-glucosidase enzyme using three buffer solutions, in soils belonging to three different orders, and ii) to evaluate the changes of enzyme activity in different soil orders after a controlled OM removal.

\section{Material and methods}

\subsection{Soil sampling and characterization}

A total of seven soils under different agricultural management were analyzed. One soil devoted to sugar cane (Saccharum officinarum), used as pasture in past, located in Puerto Lopez, Meta - Colombia $\left(04^{\circ} 5^{\prime} \mathrm{N}, 72^{\circ} 57^{\prime} \mathrm{W}\right)$ and the other six soils from different agricultural locations of central and central-southern Chile: Peumo

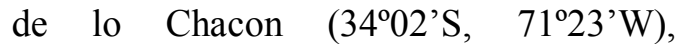
Diguillín (36 $\left.53^{\circ} \mathrm{S}, 72^{\circ} 10^{\prime} \mathrm{W}\right)$, Collipulli (36 $\left.58^{\circ} \mathrm{S}, 72^{\circ} 09^{\prime} \mathrm{W}\right)$, Metrenco (38 $34^{\prime} \mathrm{S}$,

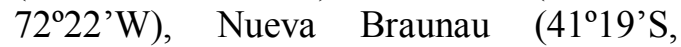
$\left.73^{\circ} 06^{\prime} \mathrm{W}\right)$, and Ralún $\left(41^{\circ} 32^{\prime} \mathrm{S}, 7^{\circ} 05^{\prime} \mathrm{W}\right)$. Peumo de lo Chacon soil is commonly used for maize (Zea mays L.) cultivation receiving high nutrient rates, particularly nitrogen and phosphorus. The other soils are dominated by variable charge components and are devoted to natural pasture with minimal or no fertilization. Information and properties of the studied soils are given in Table 1. In general terms,
Mollisols are characterized by the presence of 2:1 clay minerals with high cation exchange capacity (CEC), while volcanic soils (Andisols and Ultisols) are characterized by the presence of allophane, $\mathrm{Al}$ and $\mathrm{Fe}$ oxides, and/or kaolinite (1:1 type clay) with low CEC (Escudey et al., 2001; Violante et al., 2002).

Composite soil samples were taken from the plow layer $(0-20 \mathrm{~cm})$ of the selected soils. All samples were collected after removing roots and other plants residues. The samples were transported under refrigerated conditions in paper and sealed plastic bags to preserve their biological properties. The samples were sieved to $<2$ $\mathrm{mm}$, homogenized, and air dried, before physicochemical analyses that were performed following standard procedures recommended by the Soil Science Society of America (Spark, 1996): OM content was determined by the Walkley-Black method, exchangeable cations $(\mathrm{Na}, \mathrm{K}, \mathrm{Mg}$, and $\mathrm{Ca}$ ) were determined in ammonium acetate extracts at $\mathrm{pH} 7.0, \mathrm{pH}$ and electrical conductivity were measured in soil suspensions in a $1: 2.5 \mathrm{w} / \mathrm{v}$ soil-towater ratio, and particle size distribution (texture) was determined using the hydrometer method. Homogenized subsamples were taken at natural soil moisture for enzyme activity determination. In order to evaluate the effect of $\mathrm{OM}$ on the enzyme extraction and activity, this component was removed at different degrees from one selected soil of each order before enzyme extraction.

Table 1

Characteristics of locations and selected physicochemical characteristics of soils used in the study

\begin{tabular}{|c|c|c|c|c|c|c|c|c|c|}
\hline Soils & $\begin{array}{c}\text { Soil } \\
\text { taxonomy } \\
\text { order } \\
\end{array}$ & $\begin{array}{c}\text { Average } \\
\text { temperature } \\
\left({ }^{\circ} \mathrm{C}\right) \\
\end{array}$ & $\begin{array}{c}\text { Average annual } \\
\text { precipitation } \\
(\mathrm{m})\end{array}$ & $\begin{array}{c}\text { Sand } \\
(\%)\end{array}$ & $\begin{array}{l}\text { Silt } \\
(\%)\end{array}$ & $\begin{array}{c}\text { Clay } \\
(\%)\end{array}$ & Texture $^{(a)}$ & $\begin{array}{c}\mathrm{OM}^{(\mathrm{b})} \\
(\%)\end{array}$ & $\mathrm{pH}$ \\
\hline Puerto López & Ultisol & 17.0 & 2.0 & 64.0 & 20.0 & 16.0 & Sandy loam & 1.1 & 5.0 \\
\hline $\begin{array}{l}\text { Peumo de lo } \\
\text { Chacón }\end{array}$ & Mollisol & 14.0 & 0.41 & 35.0 & 25.2 & 39.8 & Clay loam & 2.9 & 5.4 \\
\hline Diguillín & Andisol & 15.5 & 1.5 & 32.6 & 46.0 & 21.5 & Loam & 10.3 & 5.1 \\
\hline Collipulli & Ultisol & 15.8 & 1.3 & 10.8 & 31.0 & 58.7 & Clay & 2.9 & 5.0 \\
\hline Metrenco & Ultisol & 14.6 & 1.3 & 6.5 & 52.9 & 40.6 & Silty clay & 4.0 & 4.9 \\
\hline Ralún & Andisol & 10.5 & 4.5 & 65.0 & 30.0 & 5.0 & Sandy loam & 7.9 & 4.2 \\
\hline $\begin{array}{l}\text { Nueva } \\
\text { Braunau }\end{array}$ & Andisol & 12.0 & 2.5 & 7.4 & 62.8 & 29.9 & $\begin{array}{l}\text { Silty clay } \\
\text { loam }\end{array}$ & 15.3 & 4.1 \\
\hline
\end{tabular}

${ }^{\text {(a) USDA classification. }}{ }^{(\mathrm{b})} \mathrm{OM}=$ organic matter. 
Peumo de lo Chacon (Mollisol), Nueva Braunau (Andisol), and Collipulli (Ultisol) soils were treated with hydrogen peroxide $\left(\mathrm{H}_{2} \mathrm{O}_{2}\right)$ to obtain additional samples with two different OM levels. Briefly, $100 \mathrm{~g}$ of soil sample were placed in a beaker on a water bath at $50-55^{\circ} \mathrm{C}$. The sample was thoroughly wetted with deionized (DI) water and aliquots of $5-10 \mathrm{~mL}$ of $\mathrm{H}_{2} \mathrm{O}_{2}$ $30 \%$ (v/v) were added at 3-4-hour intervals for 3-4 days (Escudey and Galindo, 1983). Sub-samples were taken at different times to check the OM content. Once the removal process was stopped, the treated samples were thoroughly washed (5 times) with DI water and centrifuged to eliminate the excess of $\mathrm{H}_{2} \mathrm{O}_{2}$. The $\mathrm{OM}$ content and $\mathrm{pH}$ of treated samples were measured in triplicate by using the same procedures above described.

\section{$2.2 \beta$-Glucosidase assays}

The $\beta$-glucosidase activity has been determined using different buffer solutions as maleate, acetate (Mangalassery et al., 2015), citrate, phosphate, and modified universal buffer (MUB) (Dick et al., 1996; Bowles et al., 2014) within the $\mathrm{pH}$ range of 5.5 and 6.5. These methods use $p$ NP linked substrates ( $p$ NP- $\beta$-D-glucopyranoside) and enzyme activity is determined by $p \mathrm{NP}$ released when soil is incubated in the corresponding buffered solution (Verchot and Borelli, 2005). The assays of enzyme activity were run in triplicate according to the methods described by Dick et al. (1996), using three different buffer solutions: MUB at $\mathrm{pH} 6.0,0.1 \mathrm{M}$ maleate at $\mathrm{pH}$ 6.5, and $0.05 \mathrm{M}$ acetate at $\mathrm{pH}$ 5.5. One gram of homogenized soil was mixed with $0.25 \mathrm{ml}$ of toluene $+4 \mathrm{ml}$ of buffer + $1 \mathrm{ml}$ of $p$ - nitrophenyl $\beta$-D-glucopyranoside (PNG) solution on an orbital shaker at $37{ }^{\circ} \mathrm{C}$. After incubation, the reaction was stopped adding $1 \mathrm{ml}$ of $0.5 \mathrm{M}$ $\mathrm{CaCl}_{2}$ and $4 \mathrm{ml}$ of $0.1 \mathrm{M}$ THAM (Trishydroxymethyl aminomethane) buffer at $\mathrm{pH}=10$, and then the solution was filtered through a Whatman $\mathrm{n}^{\circ} 2 \mathrm{v}$ folded filter paper. Controls were made following the same procedure, but the addition of substrate (PNG) was made after adding $\mathrm{CaCl}_{2}$ and THAM buffer immediately before filtration. The activity of $\beta$ glucosidase was expressed as $\mu \mathrm{g} p \mathrm{NP}$ released $\mathrm{g}^{-1}$ dry soil $\mathrm{h}^{-1}$. Many procedures recommend that buffered solutions have to be kept in contact with substrates and soil samples for 1 to $2 \mathrm{~h}$ at $37^{\circ} \mathrm{C}$ (Acosta et al., 2008; Dick et al., 1996; Bowles et al., 2014), thus the experiment was performed with the three different buffer solutions (MUB, maleate, and acetate), varying the incubation or reaction time between 30 min and $10 \mathrm{~h}$ (seven times in triplicate), in order to cover the recommended time interval. In the case of enzyme activity for the experiment of OM removal, $1 \mathrm{~h}$ of incubation time was selected.

\subsection{Statistical analysis}

The experiment was conducted in a complete randomized design with three replications. Analysis of variance was performed in SPSS, Version 11.5 for Windows. A factorial arrangement of factors was also considered. The measured effects were: the soil type, the buffer solution, the incubation time, and the corresponding interactions. Original data were not normally distributed, thus were log transformed to ensure normality (Shapiro-Wilkinson test, $\mathrm{p}<0.05$ ). Means comparison (of transformed data) was performed by the protected least significant difference (LSD) test using a $5 \%$ significance $(\mathrm{p}<0.05)$. Pearson's correlation analysis between enzyme activities (transformed) at different incubation times and soil properties was performed as well.

\section{Results and discussion}

\subsection{Evaluation of different buffers and incubation time}

The statistical analysis showed a highly significant $(\mathrm{p}<0.001)$ interaction soil $x$ buffer $x$ incubation time. Figure 1 shows the effect of buffers on the enzyme activity for the evaluated soils. On average, higher activity was obtained by using the MUB buffer compared with acetate and maleate 
ones. The enzyme activity determined after the extraction with acetate buffer was very low, and, at the longer incubation times, the absorbance units of soil samples were similar to those of the blanks, making more difficult the quantification of activity. The highest activity was recorded for Peumo de lo Chacón soil (Mollisol) after using MUB and maleate $(1 \mathrm{~h})$ buffers, and for Diguillín and Nueva Braunau soils (Andisols) after using the acetate buffer (30 $\mathrm{min})$.

The $\beta$-glucosidase activity measured after extraction with MUB buffer showed a similar trend for most soils, where the enzyme activity increased from $30 \mathrm{~min}$ to $60 \mathrm{~min}$ of extraction, afterward it decreased with time (Figure 1). Thus, for this buffer, an incubation time of $30 \mathrm{~min}$ or $\geq 120 \mathrm{~min}$ tended to underestimate the potential activity to be measured. For acetate and maleate buffers, the enzyme activity of most soils decreased with the incubation time, with the exception of Collipulli and Metrenco soils that followed the same trend observed for MUB buffer. In most soils and for each buffer, an incubation period of $1 \mathrm{~h}$ did not show significant differences with $2 \mathrm{~h}$ of incubation and allowed to express a higher potential of enzyme activity for soil comparisons. Therefore, an incubation (extracting) time of $1 \mathrm{~h}$ is reasonably adequate to determine enzyme activity. The results are in agreement with those described by Acosta et al. (2008), Deng and Tabatabai (1994), and Dick et al. (1996).

In Table 2 the enzyme activity after an incubation time of $1 \mathrm{~h}$ is presented. Both MUB and maleate buffers showed a very similar mean enzyme activity (31.8 and $31.3 \mu \mathrm{g}-p \mathrm{NP} \quad \mathrm{g}$-soil ${ }^{-1} \mathrm{~h}^{-1} \quad$ respectively), while the acetate buffer mean activity value was $8.2 \mu \mathrm{g}-p \mathrm{NP}$ g-soil ${ }^{-1} \mathrm{~h}^{-1}$. The extractant efficiency of the MUB and maleate buffers is well reflected in the case of Collipulli soil (Figure 1, Table 2), which has the highest clay content $(58.7 \%)$ and has a low OM content among all evaluated soils (Table 1). On the contrary, very low enzyme activity was obtained for the Ultisols (Puerto López, Collipulli and Metrenco soils) when using acetate buffer. Thus, in this soil type, larger differences among the evaluated buffers were recorded. Similar coefficients of variation (CV) were obtained when using the MUB and acetate buffers (average $\mathrm{CV}<5 \%$ ). The CV was larger with the use of maleate buffer because of the higher variability observed for the Collipulli and Metrenco soil samples.

It is important to keep in mind that buffer solutions are one of the most important factors to obtain reliable results and correctly interpret the enzyme activity according to soil biological functions.
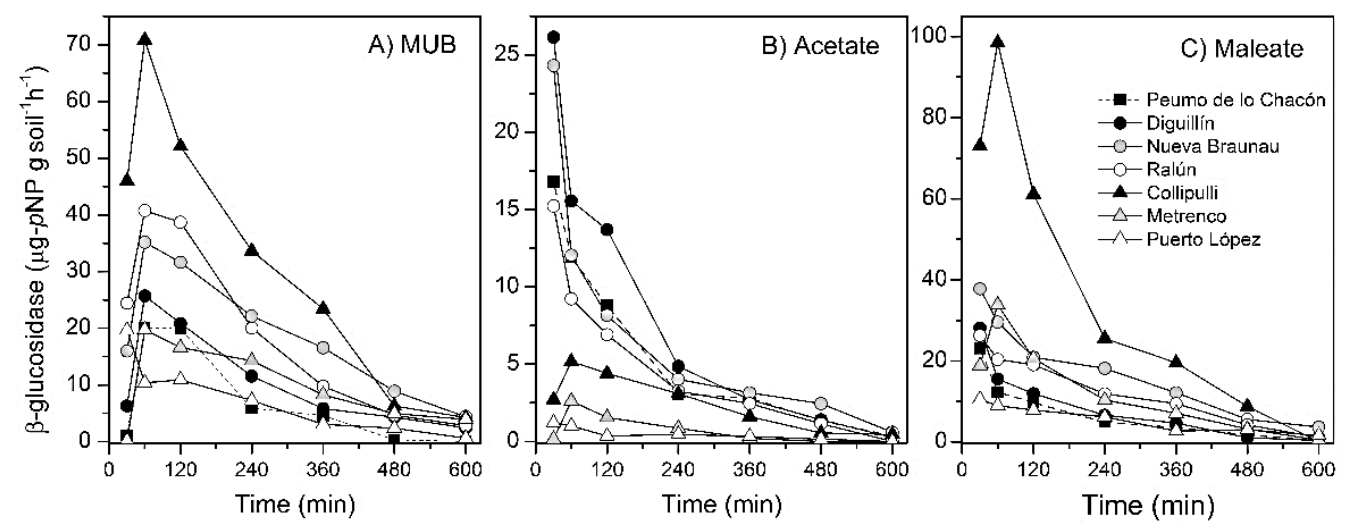

Figure 1. Soil $\beta$-glucosidase activity as affected by the incubation (extracting) time and buffer type: A) modified universal buffer (MUB), B) acetate, and C) maleate. Note that scales of $Y$ axes are different. 
There is evidence that a significant fraction of the enzyme activity measured in soil originates from abiontic enzymes (Knight and Dick, 2004). Busto and Pérez (1995) showed that the extract can contain as much as $50 \%$ of the total enzyme activity, especially for $\beta$-glucosidase. Many authors describe that abiontic enzymes can be adsorbed on clays, affecting protein conformation, and reducing their catalytic activity (Schimel et al., 2017). Different mechanisms have been suggested for $\beta$ glucosidase adsorption on soil colloids such as: electrostatic interaction, Van der Waals forces, and hydrophobic, hydrogen and covalent bonding (Quiquampoix, 1987). In general terms, the used buffers act as mild extractants, breaking down the hydrophobic bond to the non-polar organic surface and also releasing enzymes adsorbed by weak ionic bonding. All buffers are expected to extract a small amount of organically bound enzymes. The controlled assay conditions would allow releasing the proteins, allowing quantifying their activity.

In our study, MUB and maleate buffers allowed a higher enzymatic potential of free enzymes to be expressed, and, at the same time, were likely more efficient in extracting the adsorbed enzymes through some of the mechanisms above mentioned in comparison to acetate buffer in all the permanent (Mollisol) and variable-charge soils (Andisols and Ultisols). The working $\mathrm{pH}$ of MUB (6.5) and maleate (6.0) buffers could has favored the enzymatic activity. In the case of acetate buffer, Deng and Tabatabai (1994) and other authors reported that the optimal $\mathrm{pH}$ for enzyme measurement is 5.5, as used in our experiment, but Criquet (2002) reported an optimal $\mathrm{pH}$ of 6.0. For all of the variablecharge soils, the reaction $\mathrm{pH}$ of buffers is higher than the original soil $\mathrm{pH}$ (Table 1), so that the overall negative charge is increased in comparison to the natural soil condition. In general, the reported values of $\mathrm{pH}$ at which the overall surface charge equals 'cero' (isoelectric point, IEP) for $\beta$ glucosidase enzymes fall in the range 4.05.5 (Coughlan, 1985). Thus, at working $\mathrm{pH}$ of the three buffers. i.e 6.5, 6.0, and 5.5 for MUB, maleate and acetate, respectively, an overall negative surface electrical charge prevails in the adsorbent (soil) and adsorbate (enzyme protein) generating repulsion forces by charge effect. The higher the $\mathrm{pH}$ of the medium, the larger the negative charge and the repulsion forces, thus potentially decreasing the protein adsorption by electrostatic interaction (Quiquampoix, 1987; Turner, 2010) and allowing to free more enzyme to quantify its activity. In the case of the Mollisol, its permanent negative charge also repels a more negatively charged enzyme at $\mathrm{pH}$ higher than the IEP of the protein.

Table 2

Average enzyme activity and coefficient of variation (CV) as determined after an incubation (extracting) time of $1 \mathrm{~h}$ with different buffers for each soil

\begin{tabular}{lrrr}
\hline & \multicolumn{3}{c}{$\beta$-glucosidase $\left(\mu \mathrm{g}-p N P\right.$ g soil $\left.{ }^{-1} \mathrm{~h}^{-1}\right)$} \\
\cline { 2 - 4 } Soil & MUB $^{(\mathrm{a})}$ & \multicolumn{1}{c}{ Acetate } & Maleate \\
\hline Peumo de lo Chacón & $20.1 \mathrm{a}(0.1)$ & $11.9 \mathrm{~b}(3.9)$ & $12.3 \mathrm{~b}(1.4)$ \\
Diguillín & $25.7 \mathrm{a}(5.4)$ & $15.6 \mathrm{~b}(0.9)$ & $15.5 \mathrm{~b}(7.3)$ \\
Nueva Braunau & $35.2 \mathrm{a}(3.6)$ & $12.1 \mathrm{~b}(1.7)$ & $29.5 \mathrm{a}(5.6)$ \\
Ralún & $40.1 \mathrm{a}(9.7)$ & $9.2 \mathrm{c}(5.6)$ & $20.4 \mathrm{~b}(3.9)$ \\
Collipulli & $70.8 \mathrm{~b}(3.2)$ & $5.2 \mathrm{c}(2.9)$ & $98.5 \mathrm{a}(31.0)$ \\
Metrenco & $19.7 \mathrm{~b}(7.4)$ & $2.6 \mathrm{c}(10.2)$ & $33.9 \mathrm{a}(49.1)$ \\
Puerto López & $10.4 \mathrm{a}(4.7)$ & $1.0 \mathrm{~b}(4.1)$ & $9.0 \mathrm{a}(4.7)$ \\
\hline Average & $31.8(4.9)$ & $8.2(4.2)$ & $31.3(14.7)$ \\
\hline
\end{tabular}

(a)MUB: modified universal buffer. Values are mean of triplicated samples. For each soil, different letters indicate significant differences according to the LSD test $(\mathrm{p}<0.05)$. 
As mentioned, the use of the buffers with higher $\mathrm{pH}$ (MUB and maleate) led to higher values of enzyme activity (Table 2), coinciding with the repulsion effect between electrical charges. Given that variable-charge soils are complex systems, although the overall surface charge is negative, there are internal positive charges which arise from $\mathrm{Al}$ and $\mathrm{Fe}$ oxides, and allophanic components, whose reported IEP values are between 8.8-9.3 (Escudey and Galindo, 1983; Rosas et al., 2011). This positive charge can attract negatively charged $\beta$-glucosidases. In variable-charge particles, the specific adsorption of organic ligands such as maleate and citrate are well documented (e.g. Violante et al., 2002). This phenomenon also leads to competition for adsorption sites with other negative charged molecules and/or to desorption of anions electrostatically adsorbed or chemically bonded to positively charged soil components. The higher concentration of organic ligands in MUB and maleate buffers would also explain part of the increased enzyme extraction.

The values of enzymatic activity found in the evaluated soils (Figure 1, Table 2) were lower compared to those reported by Maharjan et al. (2017) under similar conditions but agree with those obtained by Merino et al. (2016) and FincheiraRobles et al. (2016) using maleate buffer for bulk soils. However, it is difficult to compare the enzymatic values because of there are several other factors affecting the activity of enzymes and microorganisms of different locations and climates such as soil OM quality and composition, in-situ range of temperatures, and soil management, as recently reviewed by Adentunji et al. (2017) and Burns et al. (2013). On average, the lowest enzyme activity was found for cultivated Puerto López and Peumo de lo Chacón soils. In general terms, cultivated soils show lower enzyme activities when compared to uncultivated soils (Acosta et al., 2008; Monreal and Bergstrom, 2000). This can be attributed to several factors: (i) the gradual loss of organic material in cultivated soils, (ii) the number of microorganisms, which are the main source of enzymes in soil, it is known to be generally reduced in agricultural soils, and (iii) the degradation rate of organic material exceeds that of humus production in soils from seasonal regions, which seriously affects the cellulolytic activity. In addition, agricultural soils are usually unprotected, where the environmental conditions more aggressively affect the native microbial populations and their metabolism in contrast to soils with abundant vegetation such as pasturelands, where there is greater protection for the biological fraction because of the groundcover provided by vegetation (Acosta et al., 2008).

Even when our study was performed a limited number of soils, it was possible to observe some clear trends from the results of correlation analysis. For example, the amount of enzyme extracted after $1 \mathrm{~h}$ by both MUB and maleate buffers were strongly correlated $(r=0.8851, p<0.001)$, where the maleate buffer had a significant relationship with clay content $(r=0.7482$, $\mathrm{p}<0.05)$. On the other hand, the acetate buffer produced the lowest enzyme activities, which were positively correlated (1 h) with $\mathrm{OM}$ in soils $(\mathrm{r}=0.7857, \mathrm{p}<0.05)$. The correlations of enzyme activity with soil properties tended to change with incubation time, in most cases without statistical significance $(\mathrm{p}>0.05$, data not shown), with the exception of MUBglucosidase activity whose correlation with OM became significant after $8 \mathrm{~h}$ of extraction $(r=0.5660 ; p<0.08)$ and the significant $(\mathrm{p}<0.05)$ correlation of acetate-glucosidase activity with $\mathrm{OM}$, that is, in general, kept with time. Some other researchers have found correlations between enzyme activity (MUB) and soil $\mathrm{pH}$ and/or clay content (Avellaneda-Torres et al., 2013; Ma et al., 2010). In spite of the significant correlation between MUB and maleate buffers, no significant relationship $(\mathrm{p}<0.05)$ was obtained for the former and any soil property. More soils need to be considered in future evaluations. The results demonstrate that 
the nature of the buffer used for estimating the $\beta$-glucosidase activity is very important. It appears that acetate buffer extracted a pool of enzymes different from that extracted by the other buffers. This behavior is influenced by various factors, including the degree of change in the enzyme's quaternary structure, the capacity of maintaining the integrity of the enzyme's active site, the proportion of protein-clay in the association, and the changes in substrate availability (Debosz et al., 1999), adding the mentioned effects of buffer composition on enzymatic activity.

\subsection{Effect organic matter removal}

Removing the OM changed significantly $(\mathrm{p}<0.05)$ the $\beta$-glucosidase activity in all treated soils (Figure 2) and, in most cases, led to a reduction of the activity. Even after the strongest $\mathrm{H}_{2} \mathrm{O}_{2}$ treatment applied to the soils $(66 \%-74 \%$ of OM removal), the enzyme activity was still feasible, and some recalcitrant $\mathrm{OM}$ was left, probably because of clay-type particles provide physical protection for OM, microbes, nutrients, and enzymes. Taking into consideration that the buffer solutions used in this study are not capable of extracting stabilized enzymes from strongly bound humus-clay complexes like other buffers do, this remaining activity represents enzymes mainly held and protected by the inorganic soil particles. The association of soil enzymes with inorganic soil colloids protects them against denaturation and inhibition (Knight and Dick, 2004; Masciandaro et al., 2008; Moscatelli et al., 2012).

The response of the Mollisol (Peumo de lo Chacón) to OM removal was different from that observed for the Andisol (Nueva Braunau) and Ultisol (Collipulli) (Figure 2 ). For the former, a reduction of $58 \%$ of its initial OM content led to a 2-fold increment of enzyme activity, then, when the OM removal reached a $69 \%$, the activity was reduced to a very low value (Figure 2A). On the other hand, there was a linear and an exponential decreasing trend for the enzyme activity with the OM removal (\%) for the Andisol and Ultisol, respectively (Figure $2 \mathrm{~B}, \mathrm{C}$ ). The data presented in Figure 2 correspond to activity values obtained after $1 \mathrm{~h}$ of incubation with MUB, but very similar trends were found for the other two buffers used (data not shown).

The Andisol (Nueva Braunau) used in this experiment is characterized by having a low cation exchange capacity and a mineral fraction dominated by allophane, showing a minor presence Al hydroxides (gibbsite) and organo-allophanic components, while kaolinite (1:1 type clay) is the dominating mineral fraction of the Ultisol (Collipulli) with trace amounts of other components (Escudey et al., 2001).
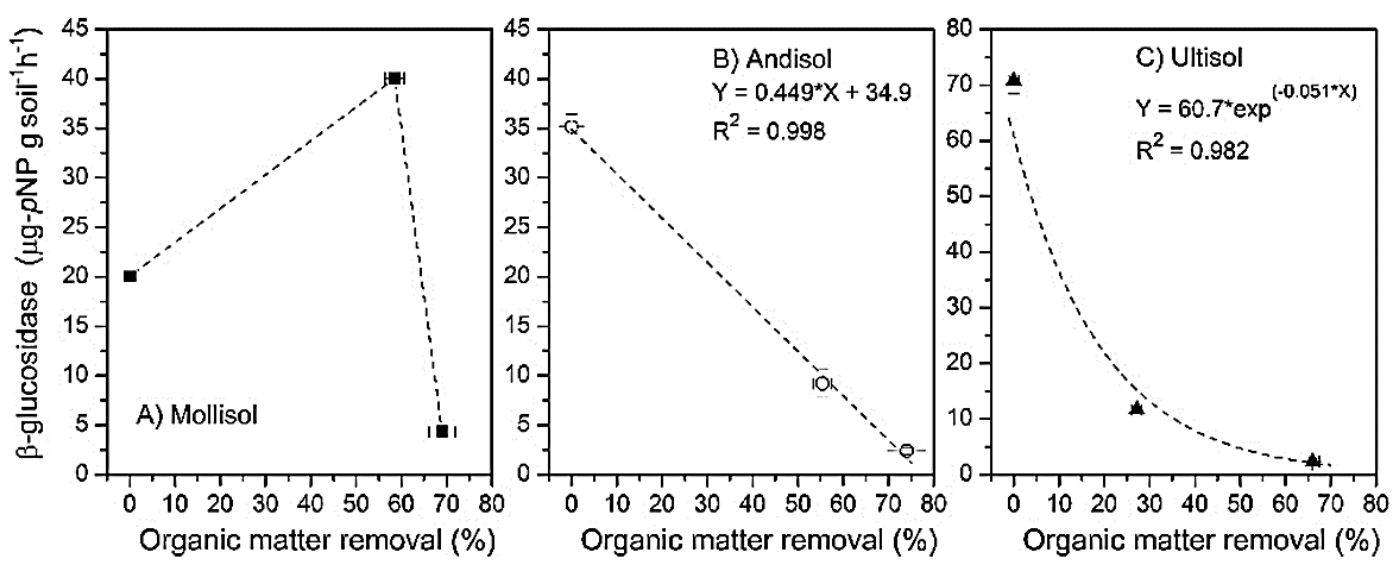

Figure 2. Effect of soil organic matter $(\mathrm{OM})$ removal $(\%)$ on soil $\beta$-glucosidase activity as measured after incubation ( $1 \mathrm{~h})$ using modified universal buffer (MUB) in three different soil orders A) Mollisol (Peumo de lo Chacón), B) Andisol (Nueva Braunau), and C) Ultisol (Collipulli). Bars show SD. Note that scales of $Y$ axes are different. 
For both soils, it was evident that the OM is the more important source compartment for enzyme activity, which markedly decreased after OM removal. However, the enzyme activity decreased more sharply for the Ultisol. For example, estimations made by using the regression equations presented in Figure $2 \mathrm{~B}$ and $\mathrm{C}$ indicated that a $50 \%$ of OM removal reduced the enzyme activity by $64 \%$ and $93 \%$ for the Andisol and Ultisol, respectively. These results may indicate that $\mathrm{OM}$ quality and/or the mineral composition of the Andisol exerted higher protection on the $\beta$ glucosidase enzymes. At this respect, Rosas et al. (2011) suggested that the network shape and pore size of the allophanic fraction in Andisols would improve soil enzymes (phosphatases) diffusion, encapsulation, and immobilization in allophane, which would not be possible when the enzymes interact with the laminar kaolinite component of Ultisols.

The Mollisol is characterized by its high clay content (2:1 type clay) and cation exchange capacity. In this case, an important fraction of its $\beta$-glucosidase enzymes may be located in the mineral fraction forming clay-enzyme complexes that, probably, showed its activity after partial removal of OM. In the original soil ('cero' OM removal), potentially active proteins may be blocked by the presence of humic matter, being not accessible to be extracted by the buffer solutions used. This is supported by the fact that humic matter has shown to exert an inhibitory effect on soil enzyme activity (Yan et al., 2010) that is explained by different mechanisms, including complexation of active sites leading to a conformational change of the enzyme, competition with the substrate for the catalytically active site, and/or binding of the substrate to humic acids (Ruggiero et al., 1996). Recently, Mazzei et al. (2013) demonstrated, using direct measurements by ${ }^{1} \mathrm{H}-\mathrm{NMR}$ spectroscopy, that humic supramolecules are able to form weakly-bond complexes with extracellular enzymes (alkaline phosphatase) that show reduced catalytic activity. When the OM removal treatment continued, more $\mathrm{OM}$ was eliminated, including proteins adsorbed to clay minerals, thus the enzyme activity finally is decreased in comparison to the initial value (Figure 2A). Clay content has both direct and indirect effects on soil biological quality and, most probably on the ability of soil to resist and recover from changes or perturbations (Nannipieri et al., 1996; Turner et al., 2002). In this line, the Mollisol may show a higher relative resilience after moderate OM degradation compared to the studied volcanic soils.

\section{Conclusions}

The use of the Modified Universal Buffer (MUB), with higher values of enzyme activity and more stable trend with time for all soils, appears to be more appropriate for $\beta$-glucosidase activity measurement in the evaluated soil orders. The best assay conditions were: use of MUB at $\mathrm{pH} 6.5$ as enzyme extractant and 1 hour of incubation time. The acetate buffer probably extracted an enzymatic pool different from that extracted by the MUB and maleate buffers. Partially removing soil OM from selected soil samples allowed us to observe the differential role of $\mathrm{OM}$ as a source and protecting factor for $\beta$-glucosidase enzymes as measured after using the different extracting agents. For the Andisol and Ultisol, an important fraction of the $\beta$ glucosidase activity was located in their OM component, while for the Mollisol, the mineral component (mainly 2:1 type clay) appeared to be involved in the increased enzyme activity displayed after the initial OM removal. These results indicate that the relative sensitivity of the extracted pool of enzyme to the partial soil OM degradation is: Ultisol >Andisol> Mollisol.

\section{References}

Acosta, V.; Acosta, D.; Sotomayor, D.; Cruz, L. 2008. Microbial communities and enzymatic activities under different management in semiarid soils. Applied Soil Ecology 38: 249-260.

Adetunji, A.T.; Lewu, F.B.; Mulidzi, R.; Ncube, B. 2017. The biological activities of $\beta$-glucosidase, phosphatase 
and urease as soil quality indicators: a review. Journal of Soil Science and Plant Nutrition 17: 794-807.

Alvear, M.; Rosas, A.; Rouanet, J.; Borie, F. 2005. Effects of three soil tillage systems on some biological activities in an Ultisol from southern Chile. Soil and Tillage Research 82: 195-202.

Avellaneda-Torres, L.; Melgarejo, M.; Narváez-Cuenca, C.; Sánchez, J. 2013. Enzymatic activities of potato crop soils subjected to conventional management and grassland soils. Journal of Soil Science and Plant Nutrition 13: 301-312.

Baldrian, P.; Snajdr, J.; Merhautová, V.; Doviasová, P.; Cajthaml, T.; Velasková, V. 2013. Responses of the extracellular enzyme activities in hardwood forest to soil temperature and seasonality and the potential effects of climate change. Soil Biology and Biochemistry 56: 60-68.

Batistic, L.; Sarkar, J.; Mayaudon J. 1980. Extraction, purification and properties of soil hydrolases. Soil Biology and Biochemistry 12: 59-63.

Blankinship, J.; Becerra, C.; Schaeffer, S.; Schimel, J. 2014. Separating cellular metabolism from exoenzyme activity in soil organic matter decomposition. Soil Biology and Biochemistry 71: 68-75.

Bowles, T.; Acosta-Martínez, V.; Calderón, F.; Jackson, L.E. 2014. Soil enzyme activities, microbial communities, and carbon and nitrogen availability in organic agroecosystems across an intensively-managed agricultural landscape. Soil Biology and Biochemistry 68: 252-262.

Burns, R.; DeForest, J.; Marxsen, J.; Sinsabaught, R.; Stromberger, M.; Wallenstein, M.; Weintraub, M.; Zoppini, A. 2013. Soil enzymes in a changing environment: Current knowledge and future directions. Soil Biology and Biochemistry 58: 216-234.

Busto, M.D.; Pérez, M. 1995. Extraction of humic $\beta-$ glucosidase fraction from soil. Biology and Fertility of Soils 20: 77-82.

Coughlan, M. 1985. The properties of fungal and bacterial cellulases with comment on their production and applications. Biotechnology and Genetic Engineering Reviews 3: 39-109.

Criquet, S. 2002. Measurement and characterization of cellulase activity in sclerophyllous forest litter. Journal of Microbiology Methods 50: 165-173.

Debosz, K.; Rasmussen, P.; Pedersen, A. 1999. Temporal variations in microbial biomass $\mathrm{C}$ and cellulolytic enzyme activity in arable soils: effects of organic matter input. Applied Soil Ecology 13: 209-218.

Deng, S.; Tabatabai M. 1994. Cellulase activity in soils. Soil Biology Biochemistry 26: 1347-1354.

Dick, R.P.; Breakwell, D.P.; Turco, R.F. 1996. Soil enzyme activities and biodiversity measurements as integrative microbiological indicators. In: Methods for Assessing Soil Quality. Soil Science Society of America, Madison, WI, USA. Pp. 247-272.

Escudey, M.; Galindo, G. 1983. Effect of iron oxide coating on electrophoretic mobility and dispersion of allophane. Journal of Colloid and Interface Science 93: 78-83.

Escudey, M.; Galindo, G.; Forster, J.; Briceño, M.; Díaz, P.; Chang, A. 2001. Chemical forms of phosphorus in volcanic ash derived soils. Communications in Soil Science and Plant Analysis 35: 601-616.

Fincheira-Robles, P.; Martínez-Salgado, M.M.; OrtegaBlu, R.; Janssens, M. 2016. Compost and humic substance effects on soil parameters of Vitis vinifera L. cv Thompson seedless. Scientia Agropecuaria 7: 291296.
Gianfreda, L.; Rao, M.; Piotrowska, A.; Palumbo, G.; Colombo, C. 2005. Soil enzyme activities affected by anthropogenic alterations: intensive agricultural practices and organic pollution. Science of the Total Environment 341: 265-279.

Gianfreda, L.; Ruggiero P. 2006. Enzyme activities in soil. In: Nucleic Acids and Proteins in Soil. Springer Verlag, Berlin, Germany. Pp. 257-311.

Kabiri, V.; Raiesi, F.; Gazhavi, M.A. 2016. Tillage effects on soil microbial biomass, SOM mineralization and enzyme activity in a semi-arid Calcixerepts. Agriculture, Ecosystems and Environment 232: 73-84.

Kanerva, S.; Smolander, A.; Kitunen, V.; Ketola, R-A.; Kotiaho, T. 2013. Comparison of extractants and applicability of MALDI-TOF-MS in the analysis of soil proteinaceous material from different types of soil. Organic Geochemistry 56: 1-9.

Kieloaho, A.; Pihlatie, M.; Dominguez-Carrasco, M.; Kanerva, S.; Parshintsev, J.; Riekkola, M.; Pumpanen, J.; Heinonsalo, J. 2016. Stimulation of soil organic nitrogen pool: The effect of plant and soil organic matter degrading enzymes. Soil Biology and Biochemistry 96: 97-106.

Knight, T.; Dick, R. 2004. Differentiating microbial and stabilized $\beta$-glucosidase activity relative to soil quality. Soil Biology and Biochemistry 36: 2089-2096.

Li, D.; Fan, J.; Zhang, X.; Xu, X.; He, N.; Wen, X.; Su, X.; Blagodatskaya, E.; Kuzyakov, Y. 2017. Hydrolyse kinetic to detect temperature-related changes in the rates of soil organic matter decomposition. European Journal of Soil Biology 81: 108-115.

Ma, X.; Chen, L.; Chen, Z.; Wu, Z.; Zhang, L.; Zhang, Y. 2010. Soil glycosidase activities and water soluble organic carbon under different land use types. Journal of Soil Science and Plant Nutrition 10: 93-101.

Maharjan, M.; Sanaullah, M.; Razavi, B.; Kuzyakov, Y. 2017. Effect of land use and management practices on microbial biomass and enzyme activities in subtropical top-and sub-soils. Applied Soil Ecology 113: 22-28.

Mangalassery, S.; Mooney. S.; Sparkes, D.; Fraser, W.; Sjögersten, S. 2015. Impacts of zero tillage on soil enzyme activities, microbial characteristics and organic matter functional chemistry in temperate soils. European Journal of Soil Biology 68: 9-17.

Masciandaro, G.; Macci C.; Doni S.; Maserti B.; CalvoBado A.; Ceccanti B.; Wellington, E. 2008. Comparison of extraction methods for recovery of extracellular $\beta$-glucosidase in two different forest soil. Soil Biology Biochemistry 40: 2156-2161.

Mazzei, P.; Oschkinat, H.; Piccolo, A. 2013. Reduced activity of alkaline phosphatase due to host-guest interactions with humic superstructures. Chemosphere 93: 1972-1979.

Merino, C.; Godoy, R.; Matus, F. 2016. Soil enzymes and biological activity at different levels of organic matter stability. Journal of Soil Science and Plant Nutrition 16: 14-30.

Monreal, C.; Bergstrom, D. 2000. Soil enzymatic factors expressing the influence of land use, tillage system and texture on soil biochemical quality. Canadian Journal of Soil Science 80: 419-428.

Moscatelli, M.; Lagomarsino, A.; Garzillo, A.; Pignataro, A.; Grego, S. 2012. $\beta$-Glucosidase kinetic parameters as indicators of soil quality under conventional and organic cropping systems applying two analytical approaches. Ecological Indicators 13: 322-327.

Nannipieri, P.; Sequi, P.; Fusi, P. 1996. Humus and enzyme activity. In: Piccolo, A. (Ed.). Humic Substances in Terrestrial Ecosystems. Elsevier, Italy. Pp. 293-321. 
Nannipieri, P.; Kandeler E.; Ruggiero P. 2002. Enzyme activities and microbiological and biochemical processes in soil. In: Burns, R.; Dick, R. (Eds.). Enzymes in the Environment. Marcel Dekker Inc. New York, USA. Pp. 1-33.

Quiquampoix, H. 1987. A stepwise approach to the understanding of extracellular enzyme activity in soil I. Effect of electrostatic interactions on the conformation of a/3-D-glucosidase adsorbed on different mineral surfaces. Biochimie 69: 753-763.

Rosas, A., López, A.; López, R. 2011. Behavior of enzymatic activity in Chilean volcanic soil and their interactions with clay fraction. In: Shukla, G.; Varma, A. (Eds.). Soil Enzymology. Springer, New York, USA. Pp. 313-328.

Ruggiero, J.; Dec, J. M.; Bollag, G. 1996. Soil as a catalytic system. In: Stotzky, G.; Bollag, J. (Eds.). Soil Biochemistry, vol. 9. Marcel Dekker, New York, USA. Pp. 79-122.

Schimel, J.; Becerra, C-A.; Blankinship, J. 2017. Estimating decay dynamics for enzyme activities in soils from different ecosystems. Soil Biology and Biochemistry 114: 5-11.

Spark, D. (Ed.). 1996. Methods of Soil Analysis, part 3, Chemical methods. Book Series $\mathrm{N}^{\circ} 5$, Soil Science Society of America, Madison, WI, USA. 1264 pp.
Tabatabai, M; Dick, W. 2002. Enzyme in soils: Research and development in measuring the activities. In: Burns, R.; Dick, R. (Eds.). Enzymes in the Environment. Marcel Dekker Inc., New York, USA. Pp. 567-596.

Turner, B. L. 2010. Variation of $\mathrm{pH}$ optima of hydrolytic enzyme activities in tropical rain forest soils. Applied and Environmental Microbiology 76, 6485-6493.

Turner, B. L.; Hopins, D. W.; Hayagarth, P. M.; Ostle, N. 2002. $\beta$-Glucosidase activity in pasture soils. Applied Soil Ecology 20: 157-162.

Verchot, L.; Borelli, T. 2005. Application of para nitrophenol (pNP) enzyme assays in degraded tropical soils. Soil Biology and Biochemistry 37: 625-633.

Violante, A.; Pigna,M.; Ricciardella, M.; Gianfreda, L. 2002. Adsorption of phosphate in variable charge minerals and soils as affected by organic and inorganic ligands. In: Violante, A.; Huang, P.; Bollag, J.; Gianfreda, L. (Eds.). Soil Mineral-Organic MatterMicroorganism Interactions and Ecosystem Health. Developments in soil science, Vol 28A. Elsevier, USA. Pp. 279-295.

Yan, J.; Pan, G.; Ding, C.; Quang, G. 2010. Kinetic and thermodynamic parameters of $\beta$-glucosidase immobilized on various colloidal particles from a paddy soil. Colloid Surface B Biointerfaces 79: 298-303. 